\title{
Data on the salinization of a coastal soil in the monsoonal rice area of Southern New Guinea ${ }^{1}$
}

H. SCHROO

Head of Soil Department, Agricultural Research Station for Netherlands New Guinea, Manokwari, Netherlands New Guinea

\section{Summary}

1. Introduction

2. Description and analysis of the standard soil profile

2.1. Profile description of the heavy, silty young marine clay

2.2. The analytical data

2.3. Conclusion

2.4. Potential production

3. Preliminary soil survey

4. Salinization of the ground water

4.1. Ground water depth

4.2. Acidity

4.3. Total salts

4.4. The chloride content

4.5. The cation concentrations

5. Salinization of the topsoil

5.1. Acidity

5.2. Salt content

5.3. Chlorine figures

5.4. Cations in the $\mathrm{NH}_{4}$-acetate percolate

6. Salinization of tilled paddy soil

Acknowledgements

\section{Summary}

A description with full analytical data and crop potentialities is given of the saline soil-type involved. Starting from the wet condition of the soil at the end of the wet season, movements of groundwater levels are measured and the salinization of ground water and topsoil are analysed at regular intervals during the pronounced dry season.

Contrary to expectations it appears that the degree of salinization of the topsoil is relatively low and is restricted to movements of free salts in the upper horizons of the profile.

Salinization of the topsoil has no direct causal relationship to the ground water which becomes very salty during the dry season.

\section{Introduction}

On both sides of the estuary of the Maro River, near the town of Merauke in the south of Netherlands New Guinea, a plain of 2 to $5 \mathrm{~km}$ wide, built up of young

1 Also published as Bulletin, Soil Science Series: No. 6 of the Agricultural Research Station at Manokwari, Netherlands New Guinea.

Received for publication 10th August, 1961.

Neth. J. agric. Sci., Vol. 9 (1961) No. 4 (November) 
marine clays, extends along the coast. This plain is the youngest part of the vast coastal plain which forms part of the Digul-Fly depression. A clear morphological description of the region has been given by REYNDERs. 1

The young marine coastal plain, with which we shall concern ourselves hereunder, lies at an average altitude of 5 to 6 meters above sea level, i.e. beyond the mean low-water spring level (LWS). On the seaside, in the lowest part of the plain, a number of elevated sand ridges run parallel to the coast in a strip from 1 to $2 \mathrm{~km}$ wide, forming a serious obstacle to the natural drainage of the plain. On the landside the plain is also bounded by sand ridges, which are considerably older and constitute a transition to a region of more ancient clays.

During the wet season (December-May) the entire plain will be $1-2$ feet under water as a result of local rainfalls and the drainage from the extensive swamps in the hinterland. Only very locally does saline water enter the plain at springtide by way of the small creeks and streams that make up the insufficient drainage system from the plain to the sea and to the Maro estuary.

Especially south of the Maro River large areas of the young marine clay are during these months used by the local population for swamp rice growing. Failing a watercontrol system in these paddies, which are entirely dependent on rain and swamp water, and due to the irregular monsoons in this area, the rice yields are generally lower than could be expected in view of the fertility of prevailing soil type.

During the dry season, however, it is impossible to grow any crops for want of irrigation water in the immediate surroundings. The soil will dry up, grow hard and crack. During the drying process the salinity of the soil will increase, due to salts being brought up by capillarity from the subsoil.

In view of the foregoing conditions the Government decided to study a 4.000 hectare rice-growing project, where by means of poldering (reclamation) and a costly irrigation system complete water control could be achieved and two rice crops per annum might be obtained. This rice area was projected in the part of the plain situated north-west of the Maro estuary. On the map (FIG. 1) this area is marked $\mathbf{J l}$.

The Soil Department of the Agricultural Research Station studied the vast grassy plain in the south-eastern part as a trial area. By means of laboratory, pot and field tests features of soil fertility as well as the soil-crop relationships were included in the research program.

One of these features was the problem of salinization, which under certain circumstances occurring during the growth cycle of the rice crop might turn out to be a harmful factor. The provisional results of this study are reviewed hereunder.

In this paper, the analytical data characterizing this type of soil will be presented and discussed in somewhat greater detail, in view of the fact that such tropical coastal soils nowadays attract considerable interest in connection with rice production.

\section{Description and analysis of the standard soil profile}

2.1. Profiledescription of the heavy, silty young arine clay $0-5 \mathrm{~cm}:$ turf layer.

5-15 cm: top soil; greyish-black to black, crumbly, silty clay with high organic matter content, containing numerous roots of non-woody vegetation.

1 Communication of The Netherlands Soil Survey Institute. Auger and Spade. XI - 1961, 104-119. 


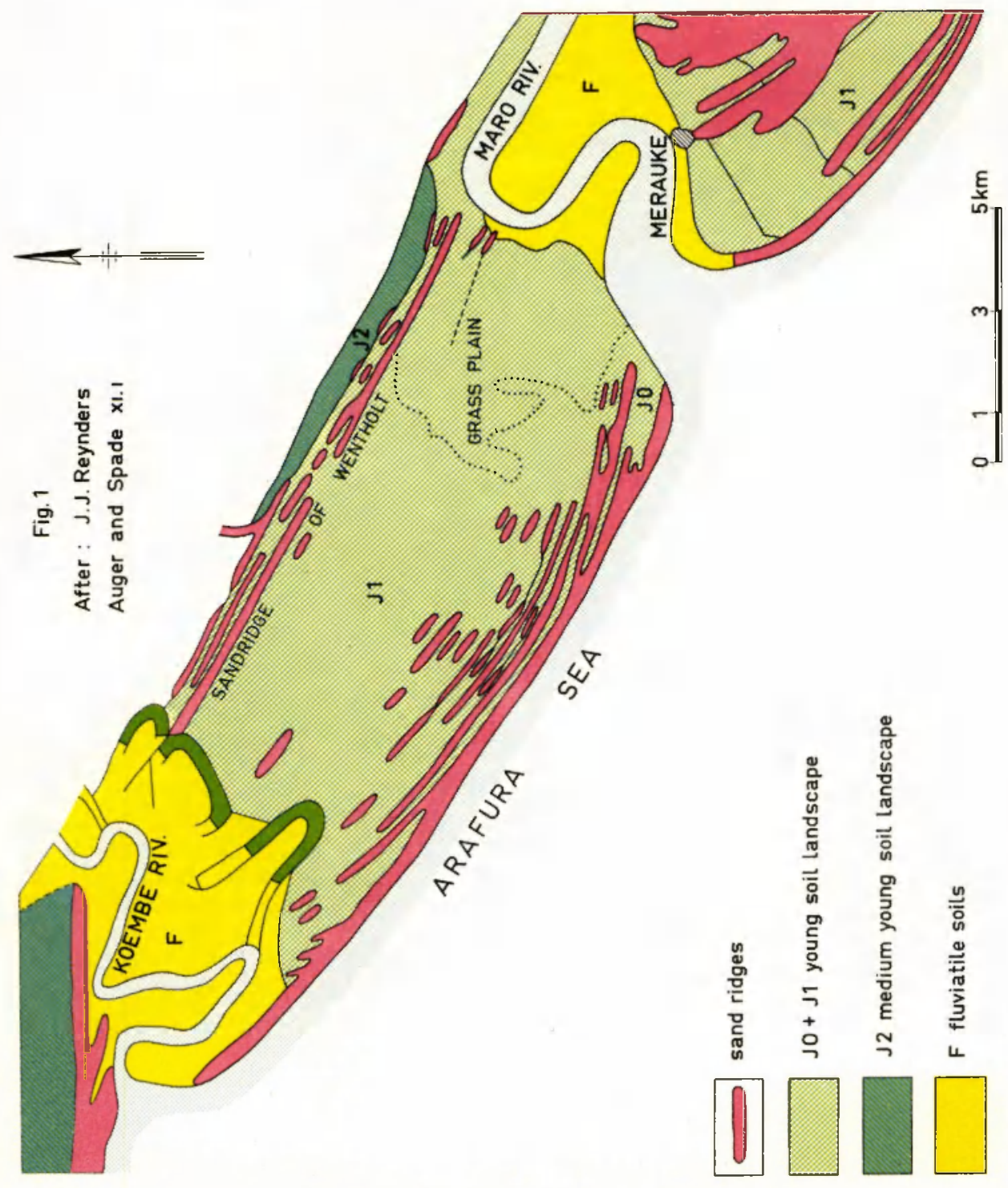


15-25 cm: transitional layer (a); mixed layer in which the black topsoil predominates, but with grey and yellowish-grey mottlings of original subsoil material; predominant colour is greyish-black.

25-35 cm: transitional layer (b); mixed layer with mainly subsoil material, but also showing dark tongue-like discolorations and stains caused by washed-down topsoil material; predominant colour is light-grey. This layer is for the greater part calcareous.

$35-60 \mathrm{~cm}$ and deeper: subsoil; bluish-grey to light-grey, crumbly, compact clay with many yellow and rusty-brown specks and small, soft iron concretions along the old root channels; dark-grey material flushed down from the topsoil is clearly visible along shrinkage fissures caused by drought. In this subsoil grass roots are still abundant. The subsoil always contains shell remnants and is highly calcareous.

As a result of the micro-relief the transitions of the above mentioned horizons will vary slightly in thickness from place to place. The thickness of the turf layer may range from 1 to $6 \mathrm{~cm}$, of the black top-layer from 7 to $22 \mathrm{~cm}$, and the transitional layers (a) and (b) together may reach a depth of $45 \mathrm{~cm}$. In the trial area the upper boundary of the free $\mathrm{CaCO}_{3}$ zone was commonly found at a depth of $28 \mathrm{~cm}$, with deviations of only a few centimetres.

During the dry season the soil shrinks considerably and becomes as hard as stone, cracking prismatically to a depth of 30 to $45 \mathrm{~cm}$. On the surface the fissures may be up to $10 \mathrm{~cm}$ wide. Each year the reed-grass vegetation is burnt up, which process enriches the soil with ashes and charcoal. In the lower parts of the area the surface of the bare soil is covered with a thin white salt crust. When the rains set in, the wide shrinkage fissures will very slowly close again. During such periods the topsoil material may be washed down into the fissures, where it is more or less moulded and mixed when the clay swells and fissures close.

In this manner the transition layer $(\mathrm{a} / \mathrm{b})$ between topsoil and subsoil was formed.

\subsection{The analytical dat a}

These are presented in TABLE 1 and refer to the standard profile under wet conditions. They reveal the following features:

The clay content of the transitional layer is higher than that of topsoil and subsoil, due to leaching of clay particles from the topsoil. As a result, the topsoil has become relatively siltier.

The carbon figures (WALKLEY BLACK) illustrate the trend of the readily oxidizable organic matter content.

The soil reaction of the topsoil is neutral, becoming strongly alkaline in the subsoil, but does not reach any value higher than 8,4 .

Free $\mathrm{CaCO}_{3}$ is only found at a depth of more than $25 \mathrm{~cm}$, and in the subsoil reaches high values of 14 per cent.

The electrical conductivity (EC) was determined on both the saturation extract and the $1: 5$ soil extract. The former EC figures are approximately four times higher than the latter. They indicate the salinity of the standard profile in very wet condition, at the end of the wet season. They provide an interesting comparison with the figures obtained for the saline topsoils in the dry season, as shown in chapter 5 . 
H. SCHROO

Table 1.

\begin{tabular}{|c|c|c|c|c|c|}
\hline \multirow[t]{2}{*}{ Analytical data 1} & \multicolumn{4}{|c|}{ Profile horizons in $\mathrm{cm}$} & \multirow[t]{2}{*}{ Units } \\
\hline & $5-15$ & $15-25$ & $25-35$ & $35-60$ & \\
\hline \\
\hline 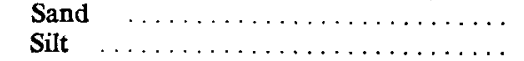 & $\begin{array}{r}2 \\
45\end{array}$ & 2 & 2 & 2 & $\%$ \\
\hline & $\begin{array}{l}45 \\
53\end{array}$ & $\begin{array}{l}31 \\
67\end{array}$ & $\begin{array}{l}33 \\
65\end{array}$ & $\begin{array}{l}40 \\
58\end{array}$ & $\begin{array}{l}\% \\
\%\end{array}$ \\
\hline Class-name & Si-clay & clay & clay & clay & - \\
\hline \multicolumn{6}{|l|}{$\begin{array}{l}\text { Organic matter } \\
\text { C \% (Walkley Black) } \ldots \ldots \ldots\end{array}$} \\
\hline C \% (Walkley Black) $\ldots \ldots$ & 4,1 & 1,6 & 0,65 & 0,35 & $\%$ \\
\hline \\
\hline 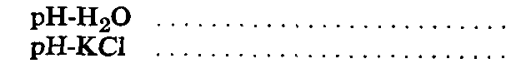 & $\begin{array}{l}7,0 \\
5,7\end{array}$ & $\begin{array}{l}7,4 \\
6,5\end{array}$ & $\begin{array}{l}8,4 \\
7,3\end{array}$ & $\begin{array}{l}8,4 \\
7,5\end{array}$ & 二 \\
\hline Free $\mathrm{CaCO}_{3}$ & 0 & 0 & 3 & 14,1 & $\%$ \\
\hline \multicolumn{6}{|l|}{$\begin{array}{l}\text { Electrical conductivity }\left(25^{\circ} \mathrm{C}\right) \\
\text { a. Saturation extrart }\end{array}$} \\
\hline $\begin{array}{l}\text { a. Saturation extrart } \ldots \ldots \ldots \\
\text { b. }(10 \mathrm{~g}: 50 \mathrm{cc}) \text { extract } \ldots \ldots\end{array}$ & $\begin{array}{r}1740 \\
455\end{array}$ & $\begin{array}{r}1860 \\
450\end{array}$ & $\begin{array}{r}2940 \\
715\end{array}$ & $\begin{array}{l}5500 \\
1390\end{array}$ & micromhos/cn \\
\hline \multicolumn{6}{|l|}{ Chlorine } \\
\hline $\mathrm{NaCl}$ in $\mathrm{H}_{2} \mathrm{O}$ extract $(10: 50)$ & 530 & 425 & 715 & 1300 & $\mathrm{mg} / \mathrm{kg}$ soil \\
\hline \multicolumn{6}{|l|}{$\begin{array}{l}\text { Solubles in } 3 \% \text { acetic acid extract } \\
(10 \mathrm{~g}: 400 \mathrm{cc})\end{array}$} \\
\hline $\mathrm{CaO} \ldots \ldots \ldots \ldots \ldots \ldots$ & $\begin{array}{l}4700 \\
(16,8)\end{array}$ & $\begin{array}{l}4300 \\
(15,4)\end{array}$ & $\begin{array}{l}17600 \\
(62,9)\end{array}$ & $\begin{array}{l}79800 \\
(285,0)\end{array}$ & $\begin{array}{l}\mathrm{mg} / \mathrm{kg} \text { soil } \\
\mathrm{m} . \mathrm{c} . / 100 \mathrm{~g}\end{array}$ \\
\hline MgO & $\begin{array}{l}2500 \\
(12,5)\end{array}$ & $\begin{array}{l}2400 \\
(12,0)\end{array}$ & $\begin{array}{l}3570 \\
(17,9)\end{array}$ & $\begin{array}{l}5250 \\
(26,3)\end{array}$ & $\begin{array}{l}\mathrm{mg} / \mathrm{kg} \text { soil } \\
\mathrm{m.c.} / 100 \mathrm{~g}\end{array}$ \\
\hline $\mathrm{Na}_{2} \mathrm{O}$ & $\begin{array}{l}1300 \\
(4,2)\end{array}$ & $\begin{array}{l}1700 \\
(5,5)\end{array}$ & $\begin{array}{l}1850 \\
(6,0)\end{array}$ & $\begin{array}{l}2450 \\
(7,9)\end{array}$ & $\begin{array}{l}\mathrm{mg} / \mathrm{kg} \text { soil } \\
\mathrm{m} . \mathrm{c.} / 100 \mathrm{~g}\end{array}$ \\
\hline $\mathrm{K}_{2} \mathrm{O}$ & $\begin{array}{l}155 \\
(0,32)\end{array}$ & $\begin{array}{l}170 \\
(0,36)\end{array}$ & $\begin{array}{l}180 \\
(0,38)\end{array}$ & $\begin{array}{l}225 \\
(0,49)\end{array}$ & $\begin{array}{l}\mathrm{mg} / \mathrm{kg} \text { soil } \\
\mathrm{m} . \mathrm{c} . / 100 \mathrm{~g}\end{array}$ \\
\hline Cation Exchange Capacity & 52,2 & 44,6 & 38,3 & 32,5 & m.c. $/ 100 \mathrm{~g}$ \\
\hline Exchangeable Ca & $(=28 \%)$ & $\left(=33 \frac{14,5}{\%}\right)$ & $(=37 \%)$ & $(=40 \%)$ & m.c. $/ 100 \mathrm{~g}$ \\
\hline Exchangeable $\mathrm{Mg}$ & $(=32 \%)$ & $\begin{array}{r}20,8 \\
(=401 / 2 \%)\end{array}$ & $(=48 \%)$ & $\left(=48 \frac{15,8}{15 \%}\right)$ & m.c. $/ 100 \mathrm{~g}$ \\
\hline Exchangeable $\mathrm{Na}$ & $(=4 \%)$ & $(=7 \%)$ & $\begin{array}{r}3,2 \\
(=8 \%)\end{array}$ & $(=10 \%)$ & m.c. $/ 100 \mathrm{~g}$ \\
\hline Exchangeable $\mathrm{K}$ & $\Leftrightarrow \begin{array}{r}0,5 \\
=1 \%)\end{array}$ & $\left(=\begin{array}{r}0,5 \\
1 \%)\end{array}\right.$ & $(=1 \%)$ & $(=11 / 2 \%)$ & m.c. $/ 100 \mathrm{~g}$ \\
\hline Total absorbed bases & 34,2 & 38,8 & 36,2 & 32,7 & m.c. $/ 100 \mathrm{~g}$ \\
\hline Saturation degree & $65 \%$ & $87 \%$ & 94\% & $100 \%$ & $\%$ \\
\hline
\end{tabular}

1 Averaged for two standard profiles sampled at the end of the wet season.

The chlorine figures (computed as $\mathrm{NaCl}$ ) show practically the same trend as the $\mathrm{EC}$ figures. This could suggest that the free salts determining the EC figures were mainly chlorides. 
The acetic acid extract gives valuable information regarding the nature of the soil salinity as far as the actions are concerned. Depending on circumstances, this extract will dissolve a greater or smaller part of the exchangeable cations. In addition, it will always contain the total of the free salts present in the soil and soil moisture. These high values for magnesium and sodium (upwards of $700 \mathrm{ppm}$ ) will be indicative of an unusually high supply of these elements. In the present case this high supply is attributable to the saline ground water. Likewise, a $\mathrm{CaO}$ figure upwards of $5000 \mathrm{ppm}$ will indicate with certainty the presence of free $\mathrm{CaCO}_{3}$; free $\mathrm{CaCO}_{3}$ will dissolve almost completely in $3 \%$ acetic acid. The potassium figures of our extract are normal, which shows that this element is not involved in the salinization.

The CEC-values (= Cation Exchange Capacity) of the subsoil amounts to $32,5 \mathrm{meq} /$ $100 \mathrm{~g}$ soil. For the topsoil this value is much higher $(52,2 \mathrm{meq})$, due to the high humus content; the transitional layers with their higher clay and humus contents also have a higher $C E C$-value than the subsoil.

The TEB-value (= Total Exchangeable Bases) in relation with the CEC-value shows the degree of base saturation of the exchange complex. For the subsoil with free $\mathrm{CaCO}_{3}$ the saturation degree is 100 per cent, but for the topsoil it is 65 per cent. It should be noted that calcium and magnesium ions are predominant in the exchange complex, whereas sodium holds a minor position.

\subsection{Classification}

Considering the foregoing data and according to the criteria established by the U.S. Salinity Laboratory (Agric. Handbook no. 60), the soil type under review may be rated among the "(non-alkali) saline soils". Their pH is lower than 8,5 ; their exchangeable sodium percentage is lower than 15 per cent of the CEC-value. Furthermore, the EC of their saturation extract is greater than $4 \mathrm{mhos} / \mathrm{cm}(=4000 \mathrm{micromhos} / \mathrm{cm})$. This criterion is met by the subsoil, but not by the wet topsoil. At a more advanced stage of drying up, however, the topsoil will also meet this criterion.

Being a saline soil in the dry season, under wet conditions this soil type is just not classable as saline soil, as will be apparent also from the data in Chapter 5 .

It is of interest to note that from a chemical point of view the soil type could be rated among the soils referred to by the Russian name "solonchak". With regard to its profile structure, however, this soil has rather the nature of a socalled "solonetz". Therefore, neither designation is applicable to this soil type.

\subsection{Potential production}

Yield accounts of rice grown by the native population, as well as field experiments conducted in the trial area, show that on this type of soil yields of $2500 \mathrm{~kg} / \mathrm{ha}$ of shelled rice may be considered normal. There are sufficient indications justifying the expectation that under optimum conditions crops of $3500 \mathrm{~kg} / \mathrm{ha}$ may be achieved.

\section{Preliminary soil survey}

In view of the high magnesium and sodium figures found in the acetic acid extract, it was decided to make special investigations into the salinization of the ground water and of the topsoil during the dry season.

First, however, preliminary investigations were made into the trend of the salinity 
figures throughout the entire trial area. To this end samples were taken in the trial area from thirty sampling sites: samples of topsoil (without sod) to an average depth of $3 \frac{1}{2}$ to $15 \mathrm{~cm}$, and of the transitional layer $(\mathrm{a} / \mathrm{b})$ to an average depth of 15 to $45 \mathrm{~cm}$. These samples were analysed for $\mathrm{Mg}$ and $\mathrm{Na}$ (in $3 \%$ acetic acid extract) as well as for $\mathrm{Cl}$ (in $\mathrm{H}_{2} \mathrm{O}$ extract).

The results of this analysis are shown in TABLE 2. The map (FIG. 2) shows the location of the sampling sites and some levelling results, which illustrate the micro-relief of the area. In this connection it should be noted that the high-water spring may be set at approximately $5,50 \mathrm{~m}$ above LWS.

TABLE 2.

\begin{tabular}{|c|c|c|c|c|c|c|c|}
\hline \multicolumn{2}{|c|}{ Field } & \multirow{2}{*}{\multicolumn{2}{|c|}{$\begin{array}{c}\text { Magnesium } \\
\text { (MgO-mg/kg soil) }\end{array}$}} & \multirow{2}{*}{\multicolumn{2}{|c|}{$\left(\mathrm{Na}_{2} \mathrm{O}-\mathrm{mg} / \mathrm{kg}\right.$ soil $)$}} & \multirow{2}{*}{\multicolumn{2}{|c|}{$\begin{array}{c}\text { Chlorine } \\
(\mathrm{NaCl}-\mathrm{mg} / \mathrm{kg} \text { soil) }\end{array}$}} \\
\hline \multirow[t]{2}{*}{ Zone } & \multirow[t]{2}{*}{ Sample } & & & & & & \\
\hline & & $\begin{array}{c}3 \frac{1}{2}-15 \\
(\mathrm{~cm})\end{array}$ & $\begin{array}{c}15-45 \\
(\mathrm{~cm})\end{array}$ & $\begin{array}{c}31 / 2-15 \\
(\mathrm{~cm})\end{array}$ & $\begin{array}{c}15-45 \\
(\mathrm{~cm})\end{array}$ & $\begin{array}{c}31 / 2-15 \\
(\mathrm{~cm})\end{array}$ & $\begin{array}{c}15-45 \\
(\mathrm{~cm})\end{array}$ \\
\hline $\mathbf{A}$ & $\begin{array}{r}1 \\
2 \\
3 \\
4 \\
5 \\
6 \\
7 \\
8 \\
9 \\
10\end{array}$ & $\begin{array}{l}1300 \\
1200 \\
1300 \\
1450 \\
1450 \\
1350 \\
1250 \\
1400 \\
1150 \\
1650\end{array}$ & $\begin{array}{r}1200 \\
800 \\
1100 \\
550 \\
1300 \\
1150 \\
1000 \\
850 \\
1150 \\
1500\end{array}$ & $\begin{array}{r}1000 \\
600 \\
850 \\
500 \\
750 \\
1150 \\
550 \\
700 \\
850 \\
1300\end{array}$ & $\begin{array}{r}1100 \\
1050 \\
1250 \\
1150 \\
850 \\
1150 \\
850 \\
1050 \\
900 \\
1750\end{array}$ & $\begin{array}{r}530 \\
70 \\
40 \\
40 \\
560 \\
700 \\
40 \\
300 \\
210 \\
810\end{array}$ & $\begin{array}{r}980 \\
2130 \\
560 \\
2130 \\
2070 \\
1140 \\
1370 \\
1550 \\
1770 \\
930\end{array}$ \\
\hline A/B & $\begin{array}{l}11 \\
12 \\
13\end{array}$ & $\begin{array}{l}1250 \\
1400 \\
1450\end{array}$ & $\begin{array}{r}350 \\
400 \\
1250\end{array}$ & $\begin{array}{l}1550 \\
1750 \\
1550\end{array}$ & $\begin{array}{l}2600 \\
3200 \\
1900\end{array}$ & $\begin{array}{r}560 \\
1510 \\
880\end{array}$ & $\begin{array}{l}2070 \\
1970 \\
1780\end{array}$ \\
\hline B & $\begin{array}{l}14 \\
15 \\
16 \\
17 \\
18 \\
19 \\
20 \\
21 \\
22\end{array}$ & $\begin{array}{l}2400 \\
1450 \\
2550 \\
2400 \\
2250 \\
2150 \\
2550 \\
2250 \\
2400\end{array}$ & $\begin{array}{l}4550 \\
5050 \\
4550 \\
3750 \\
4000 \\
5050 \\
5450 \\
5450 \\
3750\end{array}$ & $\begin{array}{r}950 \\
1250 \\
900 \\
1400 \\
1900 \\
1000 \\
1750 \\
1200 \\
2000\end{array}$ & $\begin{array}{l}1300 \\
2000 \\
2300 \\
1500 \\
2350 \\
1500 \\
2850 \\
1600 \\
2000\end{array}$ & $\begin{array}{r}630 \\
530 \\
560 \\
560 \\
1720 \\
690 \\
1680 \\
880 \\
1690\end{array}$ & $\begin{array}{r}630 \\
1890 \\
1090 \\
1070 \\
1900 \\
960 \\
2180 \\
1010 \\
1530\end{array}$ \\
\hline $\mathrm{B} / \mathrm{C}$ & $\begin{array}{l}23 \\
24 \\
25\end{array}$ & $\begin{array}{l}2550 \\
3200 \\
2650\end{array}$ & $\begin{array}{l}5750 \\
5700 \\
4400\end{array}$ & $\begin{array}{l}1600 \\
2200 \\
1250\end{array}$ & $\begin{array}{l}1550 \\
2700 \\
2000\end{array}$ & $\begin{array}{r}1850 \\
810 \\
880\end{array}$ & $\begin{array}{l}2140 \\
2470 \\
1980\end{array}$ \\
\hline C & $\begin{array}{l}26 \\
27 \\
28 \\
29 \\
30\end{array}$ & $\begin{array}{l}2650 \\
2650 \\
2950 \\
2550 \\
3600\end{array}$ & $\begin{array}{l}6000 \\
6000 \\
4800 \\
6400 \\
6900\end{array}$ & $\begin{array}{l}1950 \\
2700 \\
2800 \\
5400 \\
3150\end{array}$ & $\begin{array}{l}2350 \\
3600 \\
4150 \\
7300 \\
4850\end{array}$ & $\begin{array}{l}560 \\
580 \\
810 \\
350 \\
670\end{array}$ & $\begin{array}{l}2820 \\
4300 \\
4100 \\
7300 \\
5600\end{array}$ \\
\hline & & & & rage valu & & & \\
\hline $\begin{array}{c}\text { Zone } \\
\text { " } \\
\text { " }\end{array}$ & $\begin{array}{l}\text { A } \\
\text { B } \\
\text { C }\end{array}$ & $\begin{array}{l}1400 \\
2200 \\
2800\end{array}$ & $\begin{array}{l}1100 \\
4600 \\
6000\end{array}$ & $\begin{array}{r}800 \\
1600 \\
3200\end{array}$ & $\begin{array}{l}1100 \\
2000 \\
4000\end{array}$ & $\begin{array}{l}300 \\
900 \\
600\end{array}$ & $\begin{array}{l}1400 \\
1400 \\
4800\end{array}$ \\
\hline
\end{tabular}




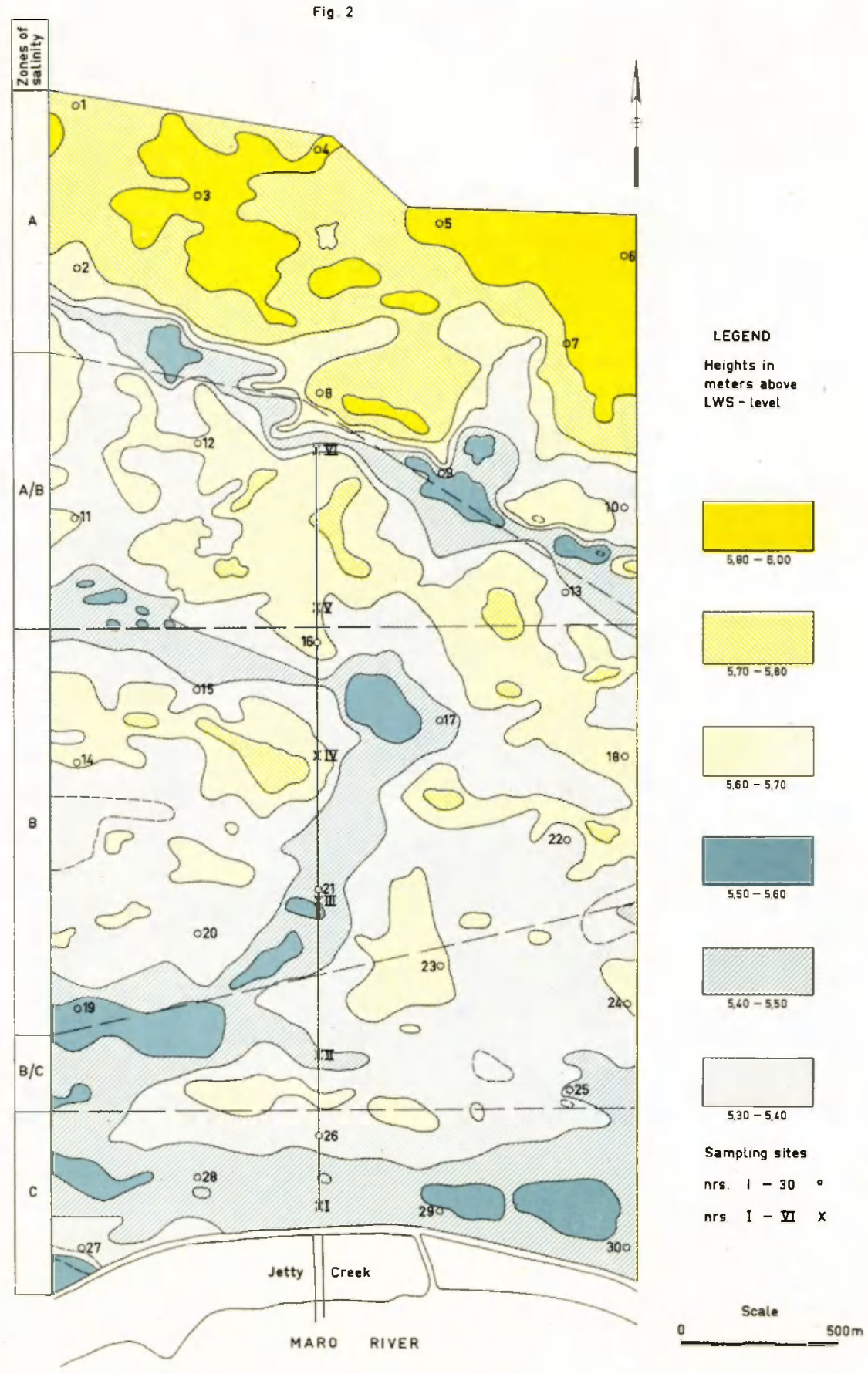

During the printing of this map the darkest and the lightest blues in the legend were interchanged: the rectangle of the 5,50-5,60 m level should be the lightest blue, the rectangle of the $5,30-5,40 \mathrm{~m}$ level the darkest. 
The preliminary survey revealed the following facts :

The area may be roughly divided from east to west into three zones, A, B and C, with the transitional zones $\mathrm{A} / \mathrm{B}$ and $\mathrm{B} / \mathrm{C}$.

Salinization decreases from south to north (from $\mathrm{C}$ to $\mathrm{A}$ ), as the lowest part of the area is in the south, where brackish water enters through a creek when the tide has reached its highest level.

In the north the area is highest and adjoins the region of the elevated sand ridges. Here the topsoil is eroded (desalinized) to the highest degree.

The difference in salinization of the three zones $\mathrm{A}, \mathrm{B}$ and $\mathrm{C}$ is most apparent from the averages shown at the foot of TABLE 2 .

Due to the micro-relief, considerable deviations from the average salinity occur in each zone. This applies in particular to the chlorine in the topsoils, as chlorine concentrations are not stabilized by the exchange complex.

With respect to the magnesium it should be pointed out that the increase in salinization from zone $A$ to $C$ is much sharper in the subsoil than in the topsoil. The proportion $\mathrm{A}: \mathrm{B}: \mathrm{C}$ in the subsoil is $1: 4: 6$, but for the topsoil this ratio is only $1: 1 \frac{1}{2}: 2$.

For the sodium the salt increase is about equal for both layers, the proportion between the zones $\mathrm{A}, \mathrm{B}$ and $\mathrm{C}$ being $1: 2: 4$.

The behaviour of the chlorine is totally different: being a non-exchangeable anion, it is much more mobile and reacts acutely on the degree of leaching. This is particularly noticeable in the topsoil.

In the higher lying soils of zone $A$, leaching prevails, whereas in the lower parts of the area, where much rainwater accumulates, the chlorine is also washed down from the topsoil to the lower layer.

The foregoing data served to select the proper sites in the area for further salinization research. For that purpose a trace was marked out, across the trial area running from South to North, along which by the end of the wet season six holes (I to VI) were bored with a clay auger at a mutual distance of 500 metres.

During the subsequent months ground-water samples were drawn and the groundwater level was measured by means of these holes with regular intervals of two weeks. The results are shown in paragraph 4 ( $\mathrm{Sal}$ in izat i o $\mathrm{n}$ of $\mathrm{th}$ e ground water). In order to evaluate also the salinization of the topsoil, samples were at the same time drawn from the topsoil at the sites I to VI, the results of which are described in paragraph 5 ( $\mathrm{Salinization}$ of $\mathrm{the} t \mathrm{tos}$ oil).

Except for sampling site I, which represents an extremely "saline" condition, the other sampling sites are representative for the average salinity of the trial area.

\section{Salinization of the ground water}

From June 20 through December 1 the six ground-water holes were sampled every two weeks. After December 1 the north-west monsoonal rains set in with great intensity.

During the sampling period total precipitation amounted only to $93 \mathrm{~mm}$, of which $28 \mathrm{~mm}$ fell during the first ten days. All water samples were examined for their $\mathrm{pH}$ and $\mathrm{EC}$, as well as for their $\mathrm{Cl}, \mathrm{Ca}, \mathrm{Mg}, \mathrm{K}$ and $\mathrm{Na}$ contents. 


\subsection{Ground-water depth}

The graphs of FIG. 3 show the depth of the ground water below field level for the six holes and the eleven dates of measuring, as well as the rainfall during the intervals. The holes had a diameter of $71 / 2 \mathrm{~cm}$, so that the loss of water caused by evaporation from the deep, narrow holes may be considered negligible.

Fig. 3 Depth of groundwater in $\mathrm{cm}$ below fleld level

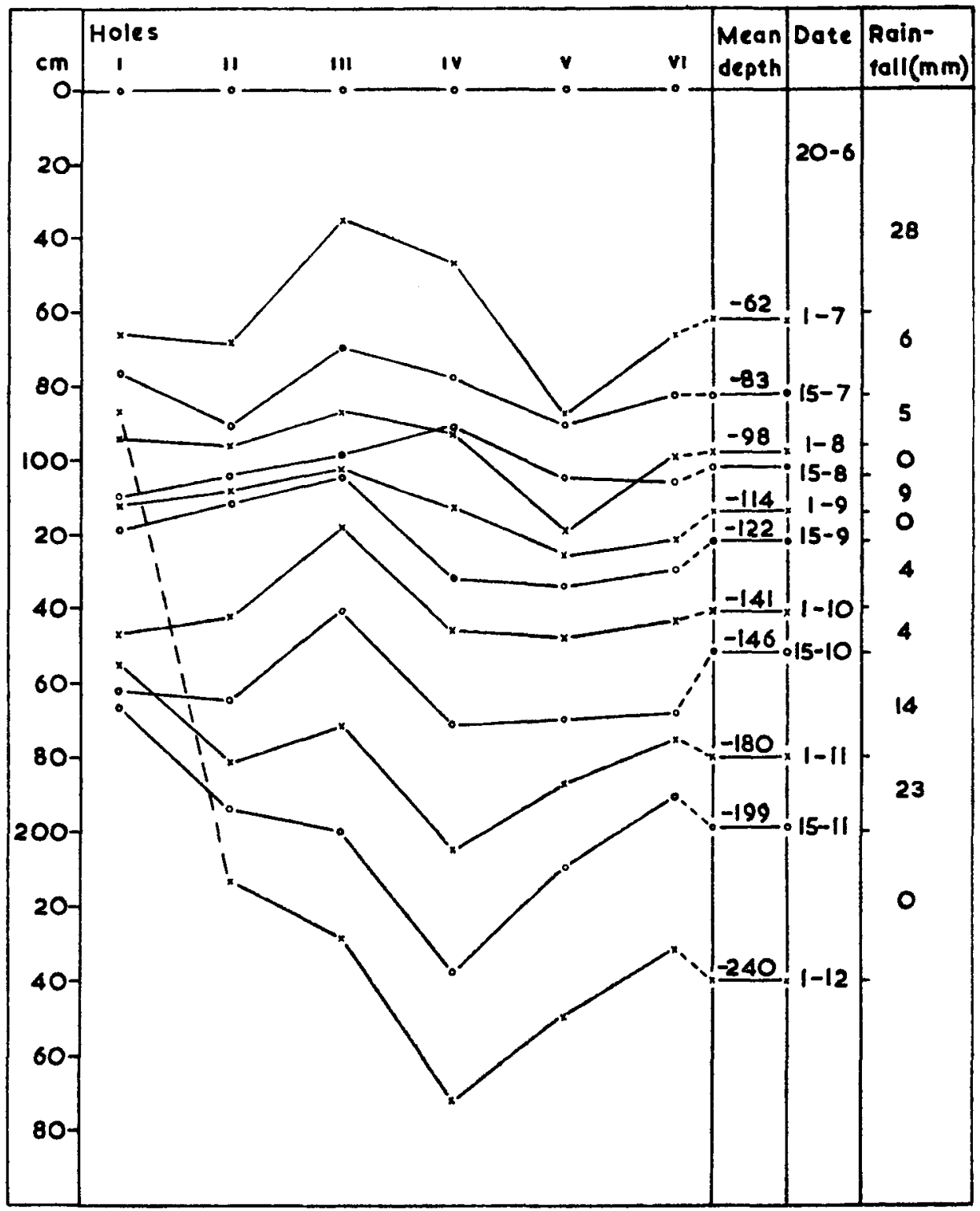


Throughout the trial period the ground-water level showed a constant decline in all holes, averaging $188 \mathrm{~cm}$ within 153 days or $12 \mathrm{~mm}$ per day. The depths of the ground water in the six holes may vary considerably. Due to a sandy layer at a greater depth in the soil profile, some of the holes must have a water supply connection with higher ground-water levels outside the trial strip.

This is evidently the case with hole I, lying 200 metres from the Maro estuary. The considerable rise in the ground-water level in this hole on December 1 is connected with high-water spring on that date.

On the other hand, the rise in the ground-water levels of holes IV and V on August 15 is attributable to a very local rain, which was rapidly sucked up by the cracked soil, thereby temporarily raising the ground-water level of those sampling sites.

\subsection{A c i d ity}

The average acidity resulting from 12 measurements for each of the six sampiing holes is illustrated by the following $\mathrm{pH}$ values:

$\mathrm{I}=7,5 ; \mathrm{II}=7,6 ; \mathrm{III}=7,7 ; \mathrm{IV}=7,7 ; \mathrm{V}=7,7 ; \mathrm{VI}=7,8$. These values are only slightly different from the overall average $\mathrm{pH}$ of 7,65 . The variations in the measurements made during the six-month measuring period are illustrated by the average $\mathrm{pH}$ values for the six holes as shown in TABLE 3 .

TABLE 3. Averaged pH-values

\begin{tabular}{|c|c|c|c|c|c|c|c|c|c|c|c|c|}
\hline Date & $20 / 6$ & $1 / 7$ & $15 / 7$ & $1 / 8$ & $15 / 8$ & $1 / 9$ & $15 / 9$ & $1 / 10$ & $15 / 10$ & $1 / 11$ & $15 / 11$ & $1 / 12$ \\
\hline pH & 7,3 & 7,4 & 7,7 & 7,8 & 8,1 & 8,1 & 8,0 & 8,0 & 7,5 & 7,5 & 7,7 & 7,4 \\
\hline
\end{tabular}

From the foregoing we may infer a trend (shown by the majority of the separate holes) of an increasing alkalinity until the end of September, followed by a gradual decline to the initial degree of low alkalinity $(\mathrm{pH}=7,4)$.

\subsection{Tot a l s a $1 \mathrm{ts}$}

The total salt content of the water samples was established through measurements of the electrical conductivity (EC) with the Philips Conductivity Measuring Bridge GM 4249. The higher the salinity, the higher the EC of the solution. The lastmentioned factor is measured at $25^{\circ} \mathrm{C}$ and is expressed in $\mathrm{mmhos} / \mathrm{cm}\left(\mathrm{EC} \times 10^{3}\right)$ (see TABLE 4).

This TABLE, showing the initial stage and the final stage as well as the average salt concentration of each hole, averaged for the entire measuring period, reveals a wide range in the salinity of the ground water of the six holes. The figures are very

TABLE 4. Salinity

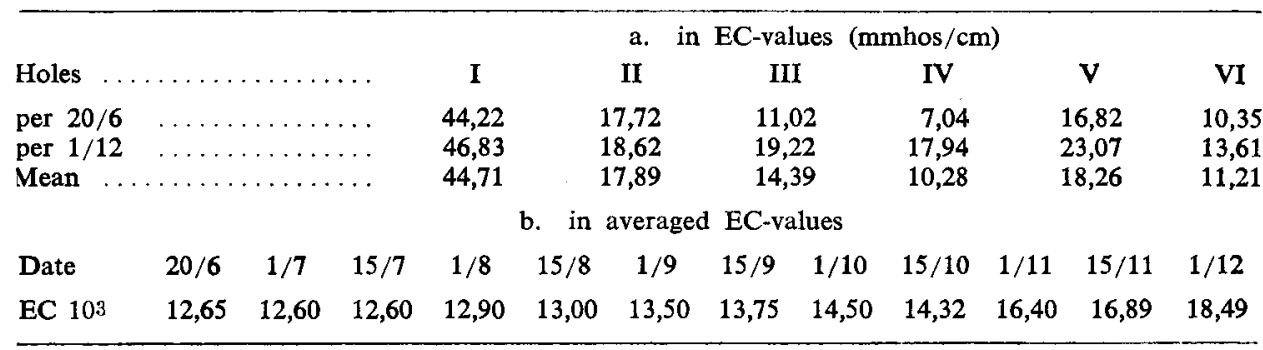


high. Even the lowest salinity reading of $7,04 \mathrm{mmhos} / \mathrm{cm}$ still corresponds with that of approximately $61 / 2$ times diluted sea-water, which measures $44-45 \mathrm{mmhos} / \mathrm{cm}$. The brackish water in the Maro estuary measured $40,85 \mathrm{mmhos} / \mathrm{cm}$ at low outflowing tide and $43,00 \mathrm{mmhos} / \mathrm{cm}$ at high in-flowing tide.

Hole No. I occupies an exceptional position on account of its peculiar location in the area. The lowest value measured is 42,6 and the highest $56,8 \mathrm{mmhos} / \mathrm{cm}$. Thus, due to the excess salts in the soil itself the ground water in this hole is even more saline than sea-water. It should be noted, however, that in sea-water the ratio between the two principal cations $\mathrm{Na}$ and $\mathrm{Mg}$ is as $4: 1$, whereas in hole No. I this ratio is $3: 1$. This means a considerable enrichment of $\mathrm{Mg}$, which also explains the increased electrical conductivity.

On computing average figures hereunder, we will leave hole I out of consideration, as this hole is not representative for the average composition of the ground water in the trial area.

From the foregoing averages it appears that the salinization declines from south to north, which corresponds with the zones $\mathrm{A}, \mathrm{B}$ and $\mathrm{C}$ found in the preliminary investigations. Hole No. $\mathrm{V}$ constitutes an exception to this trend.

A comparison between the initial and final stages further reveals an increasing salinization as the dry season advances. This increase averages 46 per cent. This is clearly demonstrated by the next series of twelve figures, illustrating the averages of the five holes (II to VI) at each sampling (see TABLE 4b).

It is obvious that the ground water is too saline for the growing of field crops. Only abundant rains during the north-west monsoon or salt-free irrigation water will be able to cause the salt content - at least in the topsoil - to decline to such an extent that at least swamp rice can be grown successfully.

In this connection it was found that the first heavy rainfall of $220 \mathrm{~mm}$ during the period from December 1 to 16, caused a considerable decline in the salt content of the holes II-VI: the average EC fell from $18,5 \mathrm{mmhos} / \mathrm{cm}$ on December 1 to $11,1 \mathrm{mmhos} / \mathrm{cm}$ on December 15 .

\subsection{The chloride content}

Like the total salt content of sea-water, which amounts to approximately $35 \mathrm{~g}$ per litre and consists for about 90 per cent of chlorides, the chloride tests (see TABLE 5) to which the ground-water samples were subjected revealed that the majority of the salts consists of chlorides. The figures are shown in TABLE 5a.

The average content of $175 \mathrm{meq} \mathrm{Cl} /$ litre corresponds with $6,4 \mathrm{~g}$ chlorine per litre. As $2 \mathrm{~g}$ chlorine/litre may be supposed to be the absolute maximum for infiltration and sprinkling water, and $5 \mathrm{~g}$ chlorine/litre is considered to render water unfit for watering livestock, these figures indicate that in view of the chlorine content the ground water in the trial area should be regarded as poisonous for agricultural and stock farming purposes. Even the lowest average for hole No. IV corresponds with as much as $5,1 \mathrm{~g}$ chlorine/litre.

The chlorine content of hole No. I equals very nearly that of sea water. On calculating for each sampling date the average chlorine content of holes Nos. II to VI, we will find an unmistakable increase of the chlorine content as the dry season advances (see TABLE 5b).

4.5. The cation concentrations

The cations $\mathrm{Ca}, \mathrm{Mg}, \mathrm{K}$ and $\mathrm{Na}$ were determined in the water samples through 


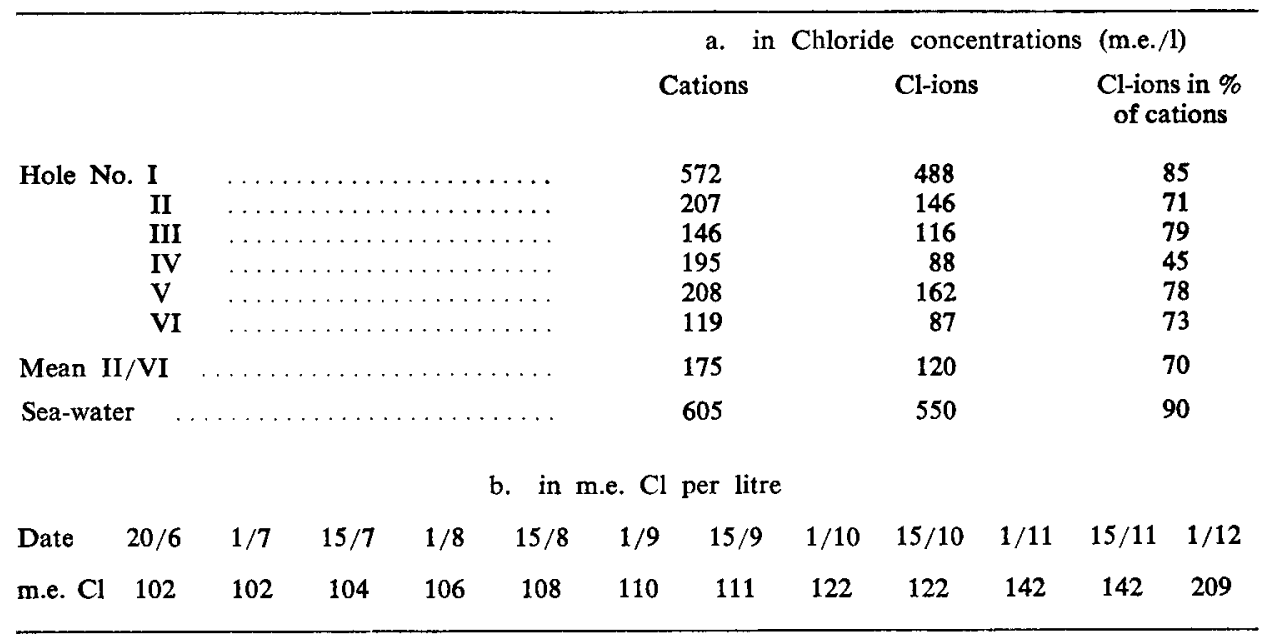

direct analysis. The concentrations of these four cations were expressed in milliequivalents per litre. The averages for the five holes Nos. II to VI for each of the twelve measurements, are shown in TABLE 6 , in which the totals of the cations are also given.

The next column shows the EC values from TABLE $4 \mathrm{~b}$ expressed in micromhos. These EC values correlate with the totals of the cations, which make up about half the total of cations and anions. Because the specific conductivity of the individual cations and anions is different, this correlation is bound to show slight deviations. This is shown in the last column of calculated cation concentration, in which the $\mathrm{EC} \times 10^{6}$ figures are divided by an experimental correlation factor 91 . For sea water this factor appears to be 74 .

TABLE 6 shows that the progressive salinization during the dry season, as found by means of the conductivity measurements, is confirmed by the total of the cations. The average increase for the holes Nos. II-VI amounts to $199,4-129,1=70,3$ meq or 54 per cent of the initial concentration. This corresponds reasonably well with the 46 per cent salinity increase earlier inferred from the EC figures.

TABLE 6 further indicates that the salinization during the dry season is mainly attributable to the sodium, as the $\mathrm{Na}$ concentration increased from 75,9 to 131,7 meq or by 73,5 per cent. On the other hand, the $\mathrm{Mg}$ content went up by a mere 39,3 per cent. A comparison between the total average cation concentration of ground water $(156,9 \mathrm{meq})$, and sea-water $(606,0 \mathrm{meq})$ shows that the ground water in the trial area may be considered a 4-fold dilution of sea-water. However, the Ca-Mg-Na cation ratio is different from that in sea water. Whereas the latter is: $\mathrm{Ca}: \mathrm{Mg}: \mathrm{Na}=$ $1: 5: 20$, the ratio in ground water on June 20 was $1: 2: 4$, but at the end of the dry season $1: 3: 8$. This shows that the composition of the ground water has the tendency of shifting towards that of sea-water.

From the overall findings we may conclude that the salinity of the ground water in the trial area increases in the dry season, which process is further promoted by sea-water which is presumably present in the deeper subsoil. 
TABLe 6. Salinity in m.e. cations/litre

\begin{tabular}{|c|c|c|c|c|c|c|c|}
\hline \multirow[t]{2}{*}{ Date } & \multicolumn{5}{|c|}{ Measured cations in m.e./litre } & \multirow{2}{*}{$\begin{array}{r}\mathrm{EC} \times 106 \\
\text { measured }\end{array}$} & \multirow{2}{*}{$\begin{array}{c}\text { Cations } \\
\text { calculated } \\
(\mathrm{EC} 106: 91)\end{array}$} \\
\hline & $\mathrm{Ca}$ & $\mathbf{M g}$ & $\mathrm{Na}$ & $\mathbf{K}$ & Total & & \\
\hline $20 / 6$ & 17,3 & 35,1 & 75,9 & 0,7 & 129,1 & 12.650 & 139 \\
\hline $1 / 7$ & 16,6 & 34,0 & 86,3 & 0,6 & 137,4 & 12.600 & 138 \\
\hline $15 / 7$ & 16,2 & 32,7 & 81,7 & 0,5 & 131,2 & 12.600 & 138 \\
\hline $1 / 8$ & 16,0 & 33,8 & 85,9 & 0,6 & 136,4 & 12.900 & 142 \\
\hline $15 / 8$ & 16,8 & 36,5 & 91,0 & 0,6 & 145,0 & 13.000 & 143 \\
\hline $1 / 9$ & 17,0 & 36,8 & 109,5 & 0,7 & 164,1 & 13.500 & 148 \\
\hline $15 / 9$ & 19,5 & 39,1 & 100,3 & 0,8 & 159,6 & 13.750 & 151 \\
\hline $1 / 10$ & 17,6 & 42,8 & 96,0 & 1,1 & 157,5 & 14.500 & 159 \\
\hline $15 / 10$ & 17,4 & 38,9 & 108,5 & 1,0 & 165,8 & 14.300 & 157 \\
\hline $1 / 11$ & 16,8 & 43,0 & 124,9 & 1,3 & 186,0 & 16.000 & 176 \\
\hline $15 / 11$ & 17,7 & 45,8 & 107,7 & 1,5 & 172,7 & 16.900 & 186 \\
\hline $1 / 12$ & 17,2 & 48,9 & 131,7 & 1,6 & 199,4 & 18.500 & 207 \\
\hline Mean & 17,2 & 38,9 & 99,9 & 0,9 & 156,9 & 12.265 & 157 \\
\hline (in $\%$ ) & 11,0 & 24,8 & 63,6 & 0,6 & 100 & & \\
\hline Sea-water & 21,0 & 108,0 & 476,0 & 10,0 & 606,0 & 45.000 & 610 \\
\hline (in \%) & 3,5 & 17,8 & 77,1 & 1,6 & 100 & & \\
\hline
\end{tabular}

\section{Salinization of the topsoil}

At the six sampling sites (I-VI) topsoil samples in duplicate were drawn in the immediate environment of the water holes during the period from June 20 to 1 st October, inclusive. After the latter date the soil was too hard for proper sampling while it could also be assumed that the salinization had reached its maximum degree.

After the rains had set in, a final sample was taken on December 15 in order to obtain an impression of the decline in salinization. The samples consisted of $5 \mathrm{~cm}$ thick slabs of black, humic topsoil, cut $1 \mathrm{~cm}$ below the underside of the turf layer parallel with the soil surface.

It was assumed that by choosing this layer the influence of occasional external factors, such as minor showers and grass-fires, would be reduced to a minimum extent by the protective action of the turf layer plus $1 \mathrm{~cm}$ of soil. On the other hand, it was considered advisable to select the sample layer as close as possible to the soil surface, where a maximum salinization would be found as a result of the evaporation of saline water rising by capillarity. It is obvious that on analysing such soil samples, irregularities in the figures will present themselves.

Samples taken from the same sampling site will already differ in organic matter content, moisture content, etc. The external factors were not constant either during the sampling period, nor were they identical for the six sampling sites. In this connection we have in mind the aforesaid local differences in precipitation, dew, and vegetation fires.

For a quantitative and qualitative investigation of the salinization, the samples were subjected to the following examinations:

Acidity ( $\mathrm{pH}$ in water extract $1: 5$ )

Salt content (EC water extract $1: 5$ )

Chlorine content (in water extract $1: 5$ ) 
SALINIZATION DATA OF A COASTAL SOIL IN THE MONSOONAL RICE AREA OF S. NEW GUINEA

$T$ value (Cation Exchange Capacity)

$\mathrm{S}$ value (total absorbed bases $\mathrm{Ca}, \mathrm{Mg}, \mathrm{Na}, \mathrm{K}$ )

As could be expected, sampling site No. I again occupies an exceptional position and is not representative for the average situation in the trial area.

\subsection{Acidity}

TABLE 7 shows that the $\mathrm{pH}$ values of the sampling sites II-VI are very near the total average of $\mathrm{pH}=6,35$. In this respect there is no fundamental difference, therefore, between the sampling sites.

However, all measurements revealed that the $\mathrm{pH}$ values of sampling site No. I were higher than those of the other sites, coming very near $\mathrm{pH}=6,9$.

The $\mathrm{pH}$ values of the measurements on December 15, after the rains had set in, show a tendency to rise to the neutral point. This corresponds with the $\mathrm{pH}$ measured by the (wet) standard profile (TABLE 1), which had a $\mathrm{pH}$ of 7,0 .

It should further be noted that the $\mathrm{pH}$ values did not show any specific trend during the dry season. The initial and final stages were more or less equal.

TABLE 7. pH-values

\begin{tabular}{llcccccc}
\hline Sampling sites No. & & II & III & IV & V & VI & Mean \\
pH (average 8 s.) & $\ldots \ldots \ldots$ & $\mathbf{6 , 3 5}$ & 6,20 & 6,55 & 6,40 & 6,25 & 6,35 \\
pH sample $15 / 12$ & $\ldots \ldots$ & 6,40 & 7,50 & 7,30 & 6,90 & 6,40 & 6,90 \\
\hline
\end{tabular}

\subsection{Salt content}

This was determined by means of EC measurements of the $1: 5$ soil extract. Thus, "salinity" means the total of electrolytes. Regardless of certain irregularities shown by the figures of TABLE 8 , the average for the six sampling sites Nos. I-VI reveal an unmistakable decline in the salinity landwards. This decline in salinity corresponds more or less with the previously found salinity zones A, B and C (see TABLE 2).

From the averages for the eight measuring dates a slight, but unmistakable trend of increasing salinity as the dry season advances, may be inferred. This increase initially follows a gradual course, but grows somewhat sharper towards the end of September.

The December 15 measuring figures give rise to the conclusion that the rains reduce the leachable salt content rapidly and bring the concentrations down to below those of the initial measurement.

TABLE 8. Salinity of soil-extract $1: 5\left(\right.$ in $\left.\mathrm{EC} \times 10^{6}\right)$

\begin{tabular}{|c|c|c|c|c|c|c|c|c|c|c|}
\hline Sampling dates & $20 / 6$ & $1 / 7$ & $15 / 7$ & $1 / 8$ & $15 / 8$ & $1 / 9$ & $15 / 9$ & $1 / 10$ & Mean & $15 / 12$ \\
\hline Site I & 4890 & 4960 & 4480 & 4170 & 4400 & 4430 & 5000 & 5130 & 4680 & - \\
\hline , II & 1110 & 1250 & 1320 & 1300 & 1620 & 1140 & 1590 & 1100 & 1300 & 1070 \\
\hline , III & 760 & 1170 & 1350 & 1110 & 970 & 1080 & 960 & 1370 & 1100 & 570 \\
\hline , IV & 1050 & 970 & 680 & 1110 & 880 & 1110 & 810 & 970 & 950 & 250 \\
\hline,$\quad \mathrm{V}$ & 430 & 450 & 470 & 430 & 570 & 460 & 420 & 770 & 500 & 170 \\
\hline , VI & 610 & 560 & 780 & 680 & 880 & 950 & 790 & 1020 & 780 & 500 \\
\hline Mean II/VI & 790 & 880 & 920 & 930 & 980 & 970 & 920 & 1050 & 930 & 510 \\
\hline
\end{tabular}


The average of 510 micromhos found on December 15 corresponds very well with the EC value of 455 micromhos of the topsoil in the standard profile (sampled in wet condition), as shown in TABLE 1 .

The absolute level of the EC values is considerable, as is demonstrated by a comparison with the experimental valuations hereunder:

Classification of saline soils according to the

Micromhos/cm EC values of the $1: 5$ soil extract $\left(\mathrm{EC} \times 10^{6}\right)$

Moist/drying-up sea shoals (without salt crust)

$6000-7000$

$2500-6000$

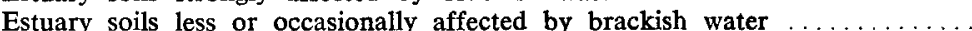

Salt-tolerance limit for most field crops

$1200-2500$

further sub-division :

"very high"

1200

$600-1200$

(poisonous range for sugar cane) $\ldots \ldots \ldots$

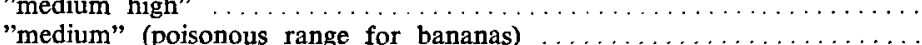

$400-600$

$300-400$

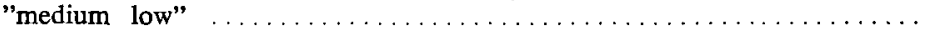

"Iow"

$200-300$

$100-200$

"very low" (normal soils)

$50-100$

up to 50

In comparison with the work of other research workers, who often use the so-called "saturation extracts", it should be noted that these extracts are approximately four times higher than the $1: 5$ extracts for the soil type and salinization process under review. For other types of saline soils, however, this ratio may be different.

\subsection{Chlorine figures}

These figures were determined through direct titration of the $1: 5$ extracts. These figures and those of TABLE 8 may, of course, be expected to correspond with each other in certain respects, in so far as the $\mathrm{Cl}$-ion is predominant and controls the influence of the anion concentration on the EC figures. Thus, the difference between sampling site $\mathrm{I}$ and the other sites shown in TABLE 8, is reflected by the $\mathrm{Cl}$ figures : the ratio of $4680: 930=5: 1$ of the EC figures in TABLE 8 amounts to $19,8: 3,0$ $=61 / 2: 1$ for the $\mathrm{Cl}$ figures in TABLE 9 .

In addition, the $\mathrm{Cl}$ figures confirm the landward decline in salinity from sampling sites II to VI.

Finally, both tables show corresponding figures for the rapid decline in salinity due to rain. In TABLE 8 this decline amounts to an average of $930-510=420$ micromhos, corresponding with $3,0-1,7=1,3$ meq of chlorine.

The gradual but slight increase in salinity as the dry season advances, which could be inferred from the EC figures in TABLE 8, is no longer apparent in TABLE 9, as the differences have become too small : in TABLE 8 the lowest average salt concentration amounts to 790 micromhos, which is 140 micromhos below the average of 930 .

On the other hand, the highest average concentration of 1050 micromhos is only 120 micromhos up from the average. This deviation of approximately 130 micromhos corresponds with $0,12 \mathrm{meq}$ of chlorine. This deviation from the average of $3,0 \mathrm{meq}$ of chlorine is within the accuracy limit of the numerical data (TABLE 9).

With respect to the absolute level of the chlorine figures, it may be said that they 
TABLE 9. Chlorine in soil-extract $1: 5$ (in m.e./100 $\mathrm{g}$ of soil)

\begin{tabular}{|c|c|c|c|c|c|c|c|c|c|c|}
\hline Dates & $20 / 6$ & $1 / 7$ & $15 / 7$ & $1 / 8$ & $15 / 8$ & $1 / 9$ & $15 / 9$ & $1 / 10$ & Mean & $15 / 12$ \\
\hline Site I & 20,7 & 21,2 & 18,8 & 17,7 & 18,7 & 19,0 & 21,0 & 21,8 & 19,8 & \\
\hline , II & 3,1 & 3,2 & 3,7 & 3,8 & 4,6 & 3,3 & 4,5 & 3,1 & 3,6 & 3,0 \\
\hline \# III & 2,5 & 3,6 & 4,4 & 3,6 & 3,2 & 3,6 & 2,8 & 3,6 & 3,4 & 1,9 \\
\hline$"$ IV & 4,1 & 3,7 & 2,5 & 4,0 & 3.1 & 4,3 & 2,4 & 3,2 & 3,4 & 0,8 \\
\hline$" \mathrm{~V}$ & 2,7 & 1.4 & 2,7 & 1,7 & 2,7 & 1,3 & 3,4 & 2,3 & 2,3 & 0,6 \\
\hline$"$ VI $\ldots \ldots \ldots \ldots$ & 1,9 & 1,6 & 3,1 & 2,2 & 2,8 & 3,1 & 2,0 & 2,6 & 2,4 & 2,0 \\
\hline Mean II/VI $\ldots \ldots \ldots$ & 2,8 & 2,7 & 3,3 & 3,1 & 3,3 & 3,1 & 3,0 & 2,9 & 3,0 & 1,7 \\
\hline
\end{tabular}

are high. The average of 3,0 meq of chlorine is equivalent to $1750 \mathrm{mg}$ of $\mathrm{NaCl}$ per $\mathrm{kg}$ of soil. In the standard profile sampled in wet condition (TABLE 1) we found approximately $500 \mathrm{mg} \mathrm{NaCl}$ per $\mathrm{kg}$ of soil.

When the rains set in, the $\mathrm{Cl}$ content of sampling site No. II shows the least decline so that total average of $1,7 \mathrm{meq}$ of chlorine is still relatively high and equals to $990 \mathrm{mg}$ of $\mathrm{NaCl}$ per $\mathrm{kg}$ of soil.

However, the figures for sites IV and V, amounting to an average of 0,7 meq of $\mathrm{Cl}$ or $410 \mathrm{mg} \mathrm{NaCl} / \mathrm{kg}$ of soil, indicate the equilibrium position under wet conditions.

\subsection{The cations in the $\mathrm{NH}_{4}$-acetate percolate}

Of all $6 \times 8 \times 2=96$ soil samples the total cation exchange capacity (CEC value) was determined, which for this sampled $5 \mathrm{~cm}$ thick layer amounts to an average of $41,9 \mathrm{meq} / 100 \mathrm{~g}$ of soil (see TABLE 10).

TABLE 10. Cations in $\mathrm{NH}_{4}$-acetate percolate (in m.e./100 $\mathrm{g}$ of soil) ${ }^{1}$

\begin{tabular}{|c|c|c|c|c|c|c|c|c|}
\hline & $\mathrm{Ca}$ & $\mathbf{M g}$ & $\mathrm{Na}$ & $\mathbf{K}$ & $\begin{array}{c}\text { Total } \\
\text { cations }\end{array}$ & $\begin{array}{l}\mathrm{Cl}- \\
\text { ions }\end{array}$ & $\begin{array}{l}\text { Surplus } \\
\text { cations }\end{array}$ & $\begin{array}{l}\text { Exchange } \\
\text { capacity }\end{array}$ \\
\hline 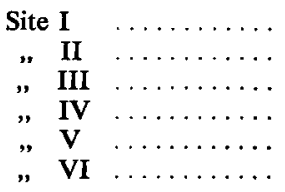 & $\begin{array}{l}22,3 \\
16,9 \\
17,9 \\
16,8 \\
17,6 \\
17,2\end{array}$ & $\begin{array}{l}16,4 \\
15,5 \\
17,9 \\
16,2 \\
15,2 \\
16,2\end{array}$ & $\begin{array}{r}22,5 \\
7,0 \\
6,4 \\
5,5 \\
4,1 \\
5,5\end{array}$ & $\begin{array}{l}1,6 \\
0,5 \\
0,2 \\
0,3 \\
0,3 \\
0,4\end{array}$ & $\begin{array}{l}62,8 \\
39,9 \\
42,4 \\
38,8 \\
37,2 \\
39,3\end{array}$ & $\begin{array}{r}19,8 \\
3,6 \\
3,5 \\
3,4 \\
2,3 \\
2,4\end{array}$ & $\begin{array}{l}43,0 \\
36,6 \\
38,9 \\
34,4 \\
34,9 \\
36,9\end{array}$ & $\begin{array}{l}39,3 \\
40,6 \\
40,1 \\
41,1 \\
42,1 \\
45,1\end{array}$ \\
\hline Mean II/VI & 17,3 & 16,1 & 5,7 & 0,3 & 39,4 & 3,0 & 36,4 & 41,8 \\
\hline
\end{tabular}

1 Each figure represents the mean $8 \times 2$ analyses.

In the $\mathrm{NH}_{4}$-acetate percolate the four cations $\mathrm{Ca}, \mathrm{Mg}, \mathrm{Na}$ and $\mathrm{K}$ were determined direct and their total was calculated. Thus, this total comprises the exchangeable cations and the free cations in the soil moisture.

The method used does not distinguish between the two categories. An approximation of the free cations was obtained from the presumption that the quantities of Cl-ions found are covered by equivalent quantities of free cations. Thus, in TABLE 10 the meq of $\mathrm{Cl}$ found was deducted from the total cations (it was assumed that the $\mathrm{Cl}$ measured in the $1: 5$ extract would be equal to that in the percolate).

The remaining "excess cations" arrived at in this manner will for the greater part consist of exchangeable cations, while a minor part will be associated as free cations with anions other than the $\mathrm{Cl}$-ion. Anyhow, the comparison between the "excess 
cation" figures and those for the "exchange capacity" shows that only sampling site No. I can have a "saturated" base exchange complex, whereas that of the other sampling sites can only have an 80 to 90 per cent base saturation.

In view of these and other reasons the relatively slight differences in salinity from place to place and from date to date, such as were found by means of the measurements of the EC of the $1: 5$ extract (TABLE 8), can not be traced back in the figures of TABLE 10.

However, this table gives rise to a few other interesting conclusions :

The first striking feature is that as compared with the average of the sampling sites II to VI, the percolate of site No. I does have the same $\mathrm{Mg}$ content, but contains more $\mathrm{Ca}, \mathrm{K}$ and particularily $\mathrm{Na}$.

In view of the $\mathrm{Cl}$ content of site No. $\mathrm{I}$, which is also much higher, it is almost certain that the excess $\mathrm{Na}$ is for the greater part present in the soil in the form of (free) $\mathrm{NaCl}$. Consequently, the exchangeable $\mathrm{Na}$ percentage will also be somewhat higher for samples $\mathbf{I}$.

The next striking feature are the fairly constant proportions, very near to the total average, of the cations for sampling sites Nos. II to VI : 17,3 meq of $\mathrm{Ca} ; 16,1 \mathrm{meq}$ of $\mathrm{Mg} ; 5,7 \mathrm{meq}$ of $\mathrm{Na}$; and 0,3 meq of $\mathrm{K}$.

On comparing these figures with those in TABLE 1 of the standard profile sampled in wet condition, it will be seen that the $\mathrm{Mg}$ and $\mathrm{K}$ have remained practically unchanged, whereas the $\mathrm{Ca}$ and $\mathrm{Na}$ have gone up a little.

Summarizing we may state that contrary to expectations the salinization of the topsoil layer of $5 \mathrm{~cm}$ thick (under the turf) is comparatively slight for the five sampling sites Nos. II to VI, and that this salinization hardly affects the base exchange complex and its composition. The salinization is mainly attributable to a temporary increase in concentration, particularly of sodium chloride, in the soil moisture. In addition, the calcium sulphate and calcium bicarbonate contents of the upper layer seem to increase temporarily, as is confirmed by the observation that both salts make up a considerable part of the salt crust, which appears here and there as a very thin coating on the soil surface.

In view of the fact that in the dry season the $\mathrm{Mg}$ content of the topsoil (in TABLE 10) is more or less equal at all sampling sites, including site No. I, while it has also remained unchanged in relation to the standard profile (TABLE 1), it must be presumed that the above mentioned salinization of the topsoil has no direct relation with the ground water found at a greater depth. It has been stated before that the $\mathrm{Mg}$ content of the ground water shows a considerable increase in the dry season.

The salinization of the upper soil layer is attributable, therefore, to the selected movement of sodium and calcium salts from the adjoining substrate to the surface. The excess salt deposits in these substrata do, of course, originate in the ground water, which in the wet season rises to near the soil surface. Thus, there is only an indirect relation between salinization and ground water.

Rainfall will soon neutralize the "salinization" described above. In the most saline parts of the area, such as sampling site No. I, the desalinization process will proceed a little more slowly.

\section{Salinization of tilled paddy soil}

Complementary to the data contained in Chapter 5, which referred to untilled soil 
under a grass cover, the figures to be discussed hereunder refer to dry, tilled paddy soil. The trial paddy plot was situated in Zone C, near sampling site 28 (FIG. 2). On this plot three spots were marked out close to each other. From these spots samples were taken in duplicate from the top $5 \mathrm{~cm}$ of soil at regular intervals. Only sampling site No. 3 had been planted with rice and was sampled on an open spot among the stubble.

On the date of commencement (July 11) site No. 1 was the relatively driest place. It further appeared that site No. 3 was the last to run dry. On the final date (September 7) the soil was stone-hard in all three spots, the drought having cracked the soil to some $30 \mathrm{~cm}$ deep.

The top centimetre of soil, which was included in the sampling, curled up and was covered with a very thin salt efflorescence.

Of the samples only the salinity in EC values of soil extracts $1: 5$ was determined (TABLE 11). Their duplos are shown for the special purpose of demonstrating the necessity in cases like the present to take a sufficient number of samples and not to rely on a few analysis results of this highly variable soil material.

TABLE 11. Salinity in EC-values of soil extracts $1: 5\left(\mathrm{EC} \times 10^{6}\right)$

\begin{tabular}{|c|c|c|c|c|c|}
\hline Sampling spot & $11 / 7$ & $23 / 7$ & $6 / 8$ & $22 / 8$ & $7 / 9$ \\
\hline 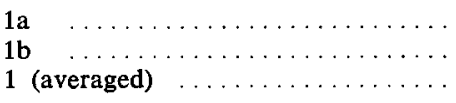 & $\begin{array}{l}2953 \\
2419 \\
2690\end{array}$ & $\begin{array}{l}3713 \\
4085 \\
3900\end{array}$ & $\begin{array}{l}3882 \\
3501 \\
3690\end{array}$ & $\begin{array}{l}4805 \\
4202 \\
4500\end{array}$ & $\begin{array}{l}5744 \\
4776 \\
5260\end{array}$ \\
\hline $\begin{array}{l}2 \mathrm{a} \\
\mathbf{2} \mathrm{b} \\
\mathbf{2} \\
2 \text { (averaged) }\end{array}$ & $\begin{array}{l}2255 \\
1971 \\
2110\end{array}$ & $\begin{array}{l}3713 \\
3519 \\
3620\end{array}$ & $\begin{array}{l}3373 \\
4429 \\
4070\end{array}$ & $\begin{array}{l}4352 \\
3891 \\
4120\end{array}$ & $\begin{array}{l}5528 \\
5931 \\
5730\end{array}$ \\
\hline $\begin{array}{l}\mathbf{3 a} \quad \ldots \ldots \ldots \ldots \\
\mathbf{3 b} \quad \ldots \ldots \ldots \ldots \\
\mathbf{3} \text { (averaged) }\end{array}$ & $\begin{array}{l}1955 \\
1785 \\
1870\end{array}$ & $\begin{array}{l}3791 \\
3373 \\
3580\end{array}$ & $\begin{array}{l}3932 \\
3535 \\
3730\end{array}$ & $\begin{array}{l}5035 \\
3810 \\
4420\end{array}$ & $\begin{array}{l}6285 \\
7210 \\
6750\end{array}$ \\
\hline Total mean & 2225 & 3700 & 3630 & 4350 & 5920 \\
\hline
\end{tabular}

The statistics in TABLE 11 are directly comparable with those shown in TABLE 8. In fact, they should be compared with EC values for sampling site I, but not with the averages for sampling sites Nos. II-VI. It is surprising, therefore, to find that these two samplings are practically on a level with each other, although the paddy sampling yields a somewhat higher total average of 5920 micromhos $/ \mathrm{cm}$. It looks as if the soil that remains moist for the greatest length of time will also record the highest final salinity. Spot 3 remained moist for the longest time, followed by spot 2 and spot 1. In moist soils, salts may still rise to the surface from the saline subsoil; in dry soil, where the water capillaries are retracted downwards, however, this process does not take place any more. It is self-evident that in paddy fields that are dependent on rain, in areas where the change of monsoons is irregular, the upper $5 \mathrm{~cm}$ layer of the soil may become highly saline while the crop is still standing in the fields.

The crop will be damaged in particular if the first rains during the sowing season cease to fall so that the very young plants are standing up to the crown of their roots in concentrated saline moisture. We do not know the extent of damage caused to the ripening crop by salinization as a result of the rice fields running dry early in the season. 
SALINIZATION DATA OF A COASTAL SOIL IN THE MONSOONAL RICE AREA OF S. NEW GUINEA

\section{ACKNOWLEDGEMENTS}

The author is indebted to two co-workers of this Soil Department.

Ir. K. A. Homans in Merauke who undertook the greater part of the fieldwork and to Mr. W. L. P. J. MouthaAN whose assistance was of great help in compiling all analytical data comprised in this paper. 